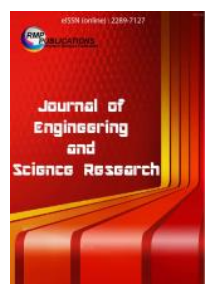

\title{
Effect of pH in SRB (ATCC 7757) Growth for Oil and Gas API X 70 Steel Pipes
}

\author{
Zuraini Din ${ }^{1}$, Khadijah Murni Ismail ${ }^{2}$, Nik Nor Asima Ariffin \\ Construction Technology Unit, Kolej Komuniti Bandar Penawar, Malaysia ${ }^{1}$ \\ Civil Engineering Department, Politeknik Sultan Haji Ahmad Shah, Malaysia ${ }^{2}$
}

\begin{abstract}
In the oil and gas industry, pipeline is the major transportation medium to deliver the products. According to [1] containment of pipeline loss to indicate that corrosion has been found to be the most predominant cause for failures of buried metal pipes. MIC has been identified as one of the major causes of underground pipeline corrosion failure and Sulphate Reducing Bacteria (SRB) are the main reason causing MIC, by accelerating corrosion rate. The objectives of this study is to study the SRB growth, Desulfovibrio desulfuricans ATCC 7757 due to $\mathrm{pH}$ and determine the optimum value controlling the bacteria growth on the internal pipe of carbon steel grade API X70. The result shows that the optimum $\mathrm{SRB}$ growth is at range $\mathrm{pH} 5-5$ to 6.5 and the exposure time of 7 to 14 days. At pH 6.5 the maximum corrosion rate is $1.056 \mathrm{~mm} /$ year. Corrosion phenomena on carbon steel in the study proven had influence by $\mathrm{pH}$ and time. From this result pitting corrosion strongly attack at carbon steel pipe. In the future project, it is recommended to study the effect of different pipe location for example the pipeline under seawater.
\end{abstract}

Key words: corrosion, microorganisms, Sulphate Reducing Bacteria (SRB), MIC

\section{Introduction}

Oil history in Malaysia started at the beginning of the $20^{\text {th }}$ century in Sarawak, where oil was first discovered in 1909 and first produced in 1910[2]. In the oil and gas industry, pipeline network system is the major transportation medium used to deliver the products to vendors. The transmission line can be buried or on the ground, but in Malaysia most of the pipes are underground because it is the safest and effective to transfer the oil and gas in bulk. The crude oil and gas pipelines in the cause of being used for the purpose of transporting products are exposed to various environments especially the offshore installations. Furthermore, the lines could be buried but eventually this exposure results in liability to various forms of external and internal corrosion problems [3].

Oil and gas transmission pipeline are critical elements of infrastructures in the transportation of fuel. Therefore, pipelines have become one of the large financial assets for the pipeline operator. Moreover, maintaining the high reliability of the pipelines has become a great concern. The expensive and high cost of replacement of crude oil production facilities which are chiefly due to corrosion activities are the factors that make it economically necessary to analyze the cost of corrosion being one of the main cost item in production cost to avoid running the oil industry at loss [4]. MIC has been identified as one of the major causes of underground pipeline corrosion failure and Sulphate Reducing Bacteria (SRB) are the main reason causing MIC, by accelerating corrosion rate. [5] studied shows that the total cost of corrosion, corrosion prevention cost is $18.05 \%$, corrosion maintenance cost is $10.21 \%$, corrosion monitoring and inspection cost is $7.74 \%$ while deferment gave the highest cost (64\%). Cost of corrosion per barrel was found to be 77 cents per barrel.

[6] studied shows that the last corrosion cost study, sponsored by the U.S. Federal Highway Administration, was conducted in 2002. The results revealed that the United States spent more than \$276 billion per year to fix corrosion issues and set up prevention measures. This equates to approximately $3 \%$ of the nation's Gross Domestic Product, which can be extrapolated to many other countries as well. Pipeline system can adversely affect people, property and the environment if oil and gas are released by mistake. As the pipelines are ageing, the economic consequences of reduced operation pressure, repairs,

\footnotetext{
*Corresponding Author: Zuraini Bt Din, Kolej Komuniti Bandar Penawar, email: zuraini@kkbpenawar.edu.my
} 
replacement and further inspection may become high.

Recent data collection studying relation of containment of pipeline loss to indicate that corrosion has been found to be the most predominant cause for failures of buried metal pipes. [1]. Seawater is often injected in addition to produced water extracted from the reservoir during oil production. Seawater brings nutrients (e.g., organic carbons) and oxidants (e.g., sulfate). It also brings various microbes including sulfate reducing bacteria (SRB) [7].

The findings from this research able to reduce the uncertainties associated with corrosion data, environmental loading and material properties. This hopefully, assists operation management in decision making on what, when and where the inspection shall be carried out, repair, maintenance and rehabilitation. Moreover, it will improve the accuracy of pipeline assessment in order to secure the pipeline reliability within a designed service period.

\section{Objective of the Study}

The aim of this research is to study the SRB growth, Desulfovibrio desulfuricans ATCC 7757. To achieve that, the study shall follow the objective below;
1. To measure the coupon metal weight loss due to corrosion on carbon steel grade API X70 due to SRB micro activity.

2. To measure the Corrosion Rate, $\mathrm{Cr}$ due to $\mathrm{pH}$.

3. To analyses the relationship between the $\mathrm{pH}$ parameter of the bacteria growth and determine the optimum value controlling the bacteria growth on the internal pipe of carbon steel grade API X70

\section{Methodology}

\subsection{Coupon Preparation}

Carbon steel pipe grade API 5L-X70 are used in this study and the pipe is used as line pipe. The sample was cut from the original API 5L-X70 from Petronas Gas Berhad (PGB) yard in oil and gas pipe into a smaller size. The carbon steel pipe was cut into $10 \mathrm{~mm} \times 20 \mathrm{~mm}$ size and the size must be in range $2.0 \mathrm{~cm}^{2}$ and it call coupon. The coupons were cut according to ASTM G1-03 [8] corrosion testing standards. Chemical composition for the coupon are determined by using X-ray dispersive spectra (EDS) and analyse the data with the standard chemical composition for steel grade API X-70 as shown in Table 3.1 and pipe physical properties in Table 3.2. Numbers of coupon that need to be prepared for the experiments are 40 numbers.

Table 3.1: Average values in weight $\%$ of chemical parameters of pipes API X70

\begin{tabular}{cccccccccccccc}
\hline $\mathbf{C}$ & $\mathbf{M n}$ & $\mathbf{S i}$ & $\mathbf{P}$ & $\mathbf{S}$ & $\mathbf{C r}$ & $\mathbf{N i}$ & $\mathbf{M o}$ & $\mathbf{V}$ & $\mathbf{T i}$ & $\mathbf{N b}$ & $\mathbf{C u}$ & $\mathbf{F e}$ \\
\hline 0.06 & \multirow{2}{*}{1.05} & 0.27 & 0.006 & 0.002 & 0.02 & 0.20 & 0.008 & 0.05 & 0.02 & 0.05 & 0.24 & $\mathrm{Bal}$ \\
\hline
\end{tabular}

Table 3.2: Pipe Physical Properties

\begin{tabular}{ccccc}
\hline API 5L Grade & $\begin{array}{c}\text { Yield Strength } \\
\text { min. } \\
(\mathrm{ksi})\end{array}$ & $\begin{array}{c}\text { Tensile Strength } \\
\text { min. } \\
(\mathrm{ksi})\end{array}$ & $\begin{array}{c}\text { Yield to Tensile } \\
\text { Ratio } \\
(\max .)\end{array}$ & $\begin{array}{c}\text { Elongation } \\
\text { min. } \\
\% \underline{1}\end{array}$ \\
\hline X70 & 70 & 82 & 0.93 & 17 \\
\hline
\end{tabular}

\subsection{Experiment Test Parameter}

$\mathrm{pH}$ is the test parameters in this study. The parameters value will vary to determine an optimal value for the bacteria growth. [9] studied shows that the optimum temperature with the highest weight loss percentage is at $37^{\circ} \mathrm{C}$. From the study shows that the $\mathrm{SRB}$ growth well at the range temperature of $20^{\circ} \mathrm{C}$ to $37^{\circ} \mathrm{C}$ and the SRB can leave longer at this temperature's range until the SRB reach the maximum exposure time of 28 days. In this study the temperature is constant at $37^{\circ}$. This experiment aims to determine the optimum $\mathrm{pH}$ for SRB growth and demonstrate the corrosion rate simulation. 
Table 3.1 shows the tested parameter. The medium temperature is constant and varies in $\mathrm{pH}$ and exposure time. There are five $\mathrm{pH}$ conditions that will be tested. The total numbers of coupon required is 40 coupons for each tested $\mathrm{pH}$. The selected $\mathrm{pH}$ value is based on the theory where in theory the corrosion occurs more rapidly in an acidic condition. The exposure times are also the tested parameter. The exposure time of the test can have a significant effect on the test data. Most material will corrode most rapidly in the early stages of coupon exposure to the environment.

Table 3.1: $\quad$ Test parameter

\begin{tabular}{cccc}
\hline $\begin{array}{c}\text { Batch } \\
\text { Experiment }\end{array}$ & $\begin{array}{c}\text { Constant } \\
\text { Parameter }\end{array}$ & Exposure Time (Day) & Variable Parameter \\
\hline 1 & $\begin{array}{c}\text { Temperature } \\
\left(37^{\circ} \mathrm{C}\right)\end{array}$ & $7,14,21$ and 28 & $\mathrm{pH}:$ \\
& & $5.5,6.5,7.5,8.5$ and 9.5 \\
\hline
\end{tabular}

\subsection{Measuring Weight Loss and Corrosion Growth Rate, $\mathrm{Cr}$}

To determine the mass loss of the coupon, the coupon shall be weighing after cleaning process. The metal loss method is the simplest uniform corrosion test. The weight loss is measured using the formulae below:

Weight Loss, $\mathrm{W}=$ Initial weight $(\mathrm{Wb})-$ after corrosion weight (Wf) (3.1)

Where :

$\mathrm{Wb}$ - weight measured before the test experiment $(\mathrm{g})$

Wf - weight taken after the exposure time

(g)

Weight Loss \% = Weight Loss (W) $\times 100$

This activity is an investigation of the corrosion of iron assuming uniform corrosion and not localized. This method measures the increase in the accumulating iron ion concentration in the test medium. The activity is completed with a calculation of the corrosion rate [10], Termology Relating to Corrosion Testing, uniform corrosion as "corrosion that proceeds at about the same rate over a metal surface." This discussion defines uniform corrosion as equivalent material loss across the continuous surface of material. The corrosion rate is expressed in metric units as millimeters per year $(\mathrm{mm} / \mathrm{yr})$.

According to Robert Babolan [11], that the analyses describes are not applicable to test specimen that show significant localized corrosion for example, if only $20 \%$ of the surface area appears attached, or if certain section have area of ten times than that the other area. The corrosion pattern shows in consistent characteristic.

The corrosion rate is calculated from the metal loss measured before and after coupon exposure, converted to a volume of metal loss by the material density, and finally the corrosion rate by dividing this volume by the material surface area and the test time. The corrosion rates are calculated from the mass loss as follows:

$$
\text { Corrosion Rate, } \mathrm{Cr}=(\mathrm{K} \times \mathrm{W}) /(\mathrm{A} \times \mathrm{T} \times \mathrm{D})
$$

Where :

$$
\mathrm{K}=\text { constant }\left(8.76 \times 10^{4}\right. \text { for corrosion }
$$

rate in $\mathrm{mm} / \mathrm{yr}$ )

$\mathrm{T}=$ time of exposure, hour

$\mathrm{A}=$ area, $\mathrm{cm}^{2}$

$\mathrm{W}=$ metal loss, $\mathrm{g}$, and

ASTM G 1)

$\mathrm{D}=$ material density, $\mathrm{g} / \mathrm{cm}^{3}$ (Refer to

\section{Result and Discussion}

The corrosion due to $\mathrm{pH}$ condition by kept the temperature constant and variation in $\mathrm{pH}$ and exposure time. The temperature is constant at $37^{\circ} \mathrm{C}$ as a result from previous analysis. This experiment aims to determine the optimum $\mathrm{pH}$ for SRB growth and demonstrate the corrosion rate simulation. Weight loss technique has been used to measure the corrosion of the coupon. The percentage of weight loss evaluated from weight loss data as presented in Table 4.1. 
Zuraini Din, Khadijah Murni Ismail \& Nik Nor Asima Ariffin/ Journal of Engineering and Science Research,3(1) 2019, Pages:30-36

Table 4.1: $\quad$ Percentage of weight loss sample with different $\mathrm{pH}$ and exposure time

\begin{tabular}{cccccc}
\hline \multirow{2}{*}{$\begin{array}{c}\text { Exposure Time } \\
\text { (day) }\end{array}$} & $\mathbf{p H 5 . 5}$ & $\mathbf{p H 6 . 5}$ & $\mathbf{p H 7 . 5}$ & $\mathbf{p H 8 . 5}$ & $\mathbf{p H 9 . 5}$ \\
\cline { 2 - 6 } & 0 & 0 & 0 & 0 & 0 \\
7 & 1.975 & 3.020 & 2.185 & 1.800 & 1.490 \\
14 & 4.600 & 0.320 & 0.600 & 1.625 & 1.085 \\
21 & 3.224 & 0.630 & 0.505 & 0.400 & 0.710 \\
28 & 1.030 & 0.730 & 0.855 & 0.915 & 0.355 \\
\hline
\end{tabular}

Based on the above table, found that $\mathrm{pH} 5.5$ give the maximum percentage of weight loss and Figure 4.1 illustrates that result. The optimum percentage of weight loss is $4.6 \%(0.046 \mathrm{~g})$ at exposure time of 14 days. At 1 to 14 day is the stage of called exponential phase. During this stage, percentage of weight loss increase quickly due to the number of active SRB.
After day 14, the percentage of weight loss is decreasing and the minimum weight loss is $1.030 \%$ $(0.0103 \mathrm{~g})$ at day 28 . The decreasing value show the reduce numbers of bacteria. The correlation coefficient, $\mathrm{R}^{2}$ of this graph is $0.916\left(0.5<\mathrm{R}^{2}<1.0\right)$ which shown that $\mathrm{pH}$ and exposure time are closely related and acceptable.

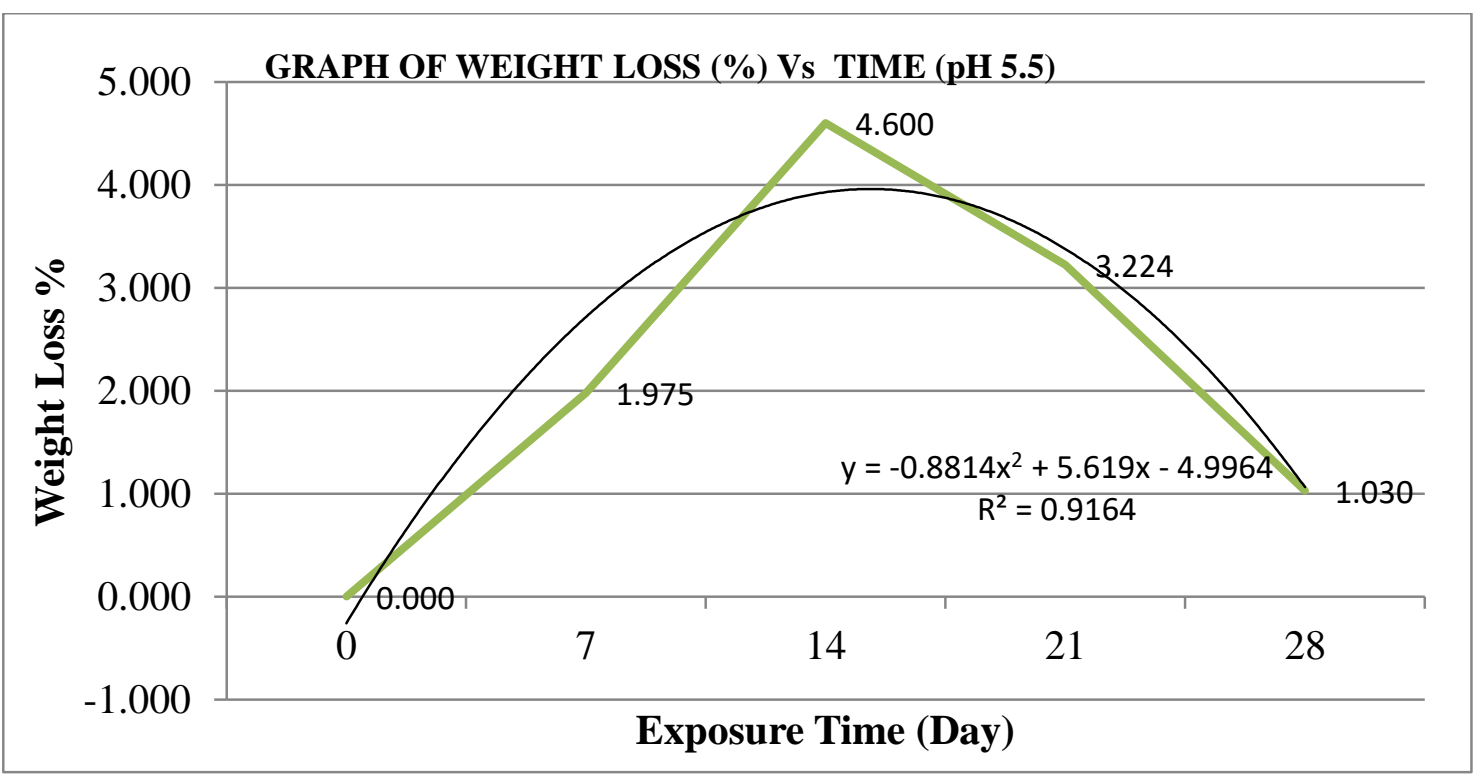

Figure 4.1: Percentage of weight loss at $\mathrm{pH} 5.5$

Figure 4.2 illustrate the percentage of weight loss against tested $\mathrm{pH}$. The chart is to show the effect of $\mathrm{pH}$ to bacteria growth. The maximum percentage of weight loss is at pH5.5 and the exposure time of 14 days. From the chart, at early exposure time, the SRB grow is high. 

Pages:30-36

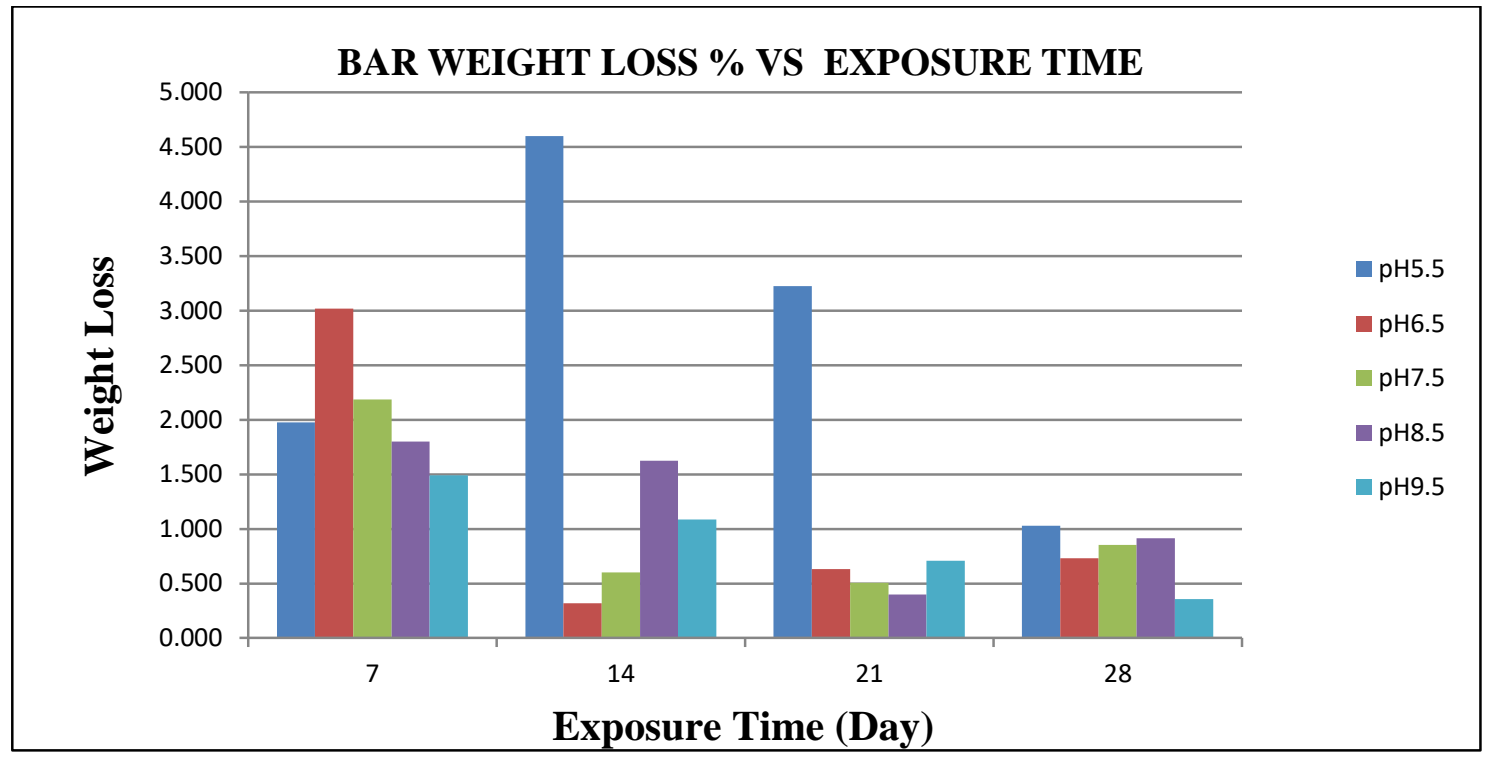

Figure 4.2: Bar Chart Weight loss \% against exposure time at variable $\mathrm{pH}$

Table 4.2 is the $\mathrm{Cr}$ at tested $\mathrm{pH}$. The corrosion rate against exposure time graph is tabulated in Figure 4.3.. At $\mathrm{pH}$ 5.5, $\mathrm{Cr}$ can be divided into three stages. 1 to 14 days is the first stage called exponential phase. During this stage, the $\mathrm{Cr}$ increase quickly and the $\mathrm{Cr}$ achieve the maximum value $0.666 \mathrm{~mm} /$ year at day 14. During the exponential phase, the $\mathrm{Cr}$ increase with increasing of exposure time. At 14 day, the $\mathrm{Cr}$ reaches the second stage naming death and residual phase. The $\mathrm{Cr}$ decreased quickly during this stage.

At $\mathrm{pH}$ 6.5, the corrosion value $1.056 \mathrm{~mm} / \mathrm{yr}$ is maximum at day 7 and this value also the optimum $\mathrm{Cr}$ from all the tested $\mathrm{pH}$. From day 7 to 14 day, the $\mathrm{Cr}$ is decreasing tremendously until the $\mathrm{Cr}$ reaches the minimum value of $0.051 \mathrm{~mm} / \mathrm{yr}$. At day 21 , the $\mathrm{Cr}$ increased to $0.073 \mathrm{~mm} / \mathrm{yr}$ and decreased to 0.055 $\mathrm{mm} / \mathrm{yr}$ after 28 days.

Table 4.2 : Corrosion rate, $\mathrm{Cr}$ (mm/year) at variable $\mathrm{pH}$

\begin{tabular}{|c|c|c|c|c|c|c|}
\hline \multirow[t]{2}{*}{ pH } & \multirow{2}{*}{$\begin{array}{c}\text { Exposure } \\
\text { Time } \\
\text { (Day) }\end{array}$} & $\begin{array}{c}\text { Time } \\
\mathbf{T}\end{array}$ & $\begin{array}{c}\text { Constant } \\
\text { K } \\
\end{array}$ & {$\left[\left(\mathbf{W}_{0}-\mathbf{W f}\right) /(\mathbf{A})\right]$} & $\begin{array}{c}\text { Density } \\
\text { D }\end{array}$ & $\begin{array}{c}\text { Corrosion } \\
\text { rate, } \mathrm{Cr}\end{array}$ \\
\hline & & (hr) & $(\mathrm{mm} / \mathrm{yr})$ & $\left(\mathrm{g} / \mathrm{cm}^{2}\right)$ & $(\mathrm{g} / \mathrm{cm} 3)$ & $\mathrm{mm} /$ year \\
\hline \multirow[t]{4}{*}{5.5} & 7 & 168 & 87600 & 0.009056517 & 7.86 & 0.600804943 \\
\hline & 14 & 336 & 87600 & 0.020072260 & 7.86 & 0.665791980 \\
\hline & 21 & 504 & 87600 & 0.016445866 & 7.86 & 0.363670240 \\
\hline & 28 & 672 & 87600 & 0.009298127 & 7.86 & 0.154208301 \\
\hline \multirow[t]{5}{*}{6.5} & 7 & 168 & 87600 & 0.015918195 & 7.86 & 1.056005318 \\
\hline & 14 & 336 & 87600 & 0.001537870 & 7.86 & 0.051010775 \\
\hline & 21 & 504 & 87600 & 0.003283302 & 7.86 & 0.072604220 \\
\hline & & & & 0.003294478 & & 0.054638522 \\
\hline & 28 & 672 & 87600 & & 7.86 & \\
\hline
\end{tabular}


Zuraini Din, Khadijah Murni Ismail \& Nik Nor Asima Ariffin/ Journal of Engineering and Science Research,3(1) 2019, Pages:30-36

\begin{tabular}{|c|c|c|c|c|c|c|}
\hline \multirow[t]{4}{*}{7.5} & 7 & 168 & 87600 & 0.009668355 & 7.86 & 0.641393994 \\
\hline & 14 & 336 & 87600 & 0.002890870 & 7.86 & 0.095889443 \\
\hline & 21 & 504 & 87600 & 0.002356950 & 7.86 & 0.052119627 \\
\hline & 28 & 672 & 87600 & 0.003962920 & 7.86 & 0.065724546 \\
\hline \multirow[t]{4}{*}{8.5} & 7 & 168 & 87600 & 0.009030138 & 7.86 & 0.599054962 \\
\hline & 14 & 336 & 87600 & 0.007462515 & 7.86 & 0.247529812 \\
\hline & 21 & 504 & 87600 & 0.001912777 & 7.86 & 0.042297573 \\
\hline & 28 & 672 & 87600 & 0.004746343 & 7.86 & 0.07871752 \\
\hline \multirow[t]{4}{*}{9.5} & 7 & 168 & 87600 & 0.007126288 & 7.86 & 0.472754498 \\
\hline & 14 & 336 & 87600 & 0.005716749 & 7.86 & 0.189623157 \\
\hline & 21 & 504 & 87600 & 0.003329894 & 7.86 & 0.073634515 \\
\hline & 28 & 672 & 87600 & 0.001731243 & 7.86 & 0.028712452 \\
\hline
\end{tabular}

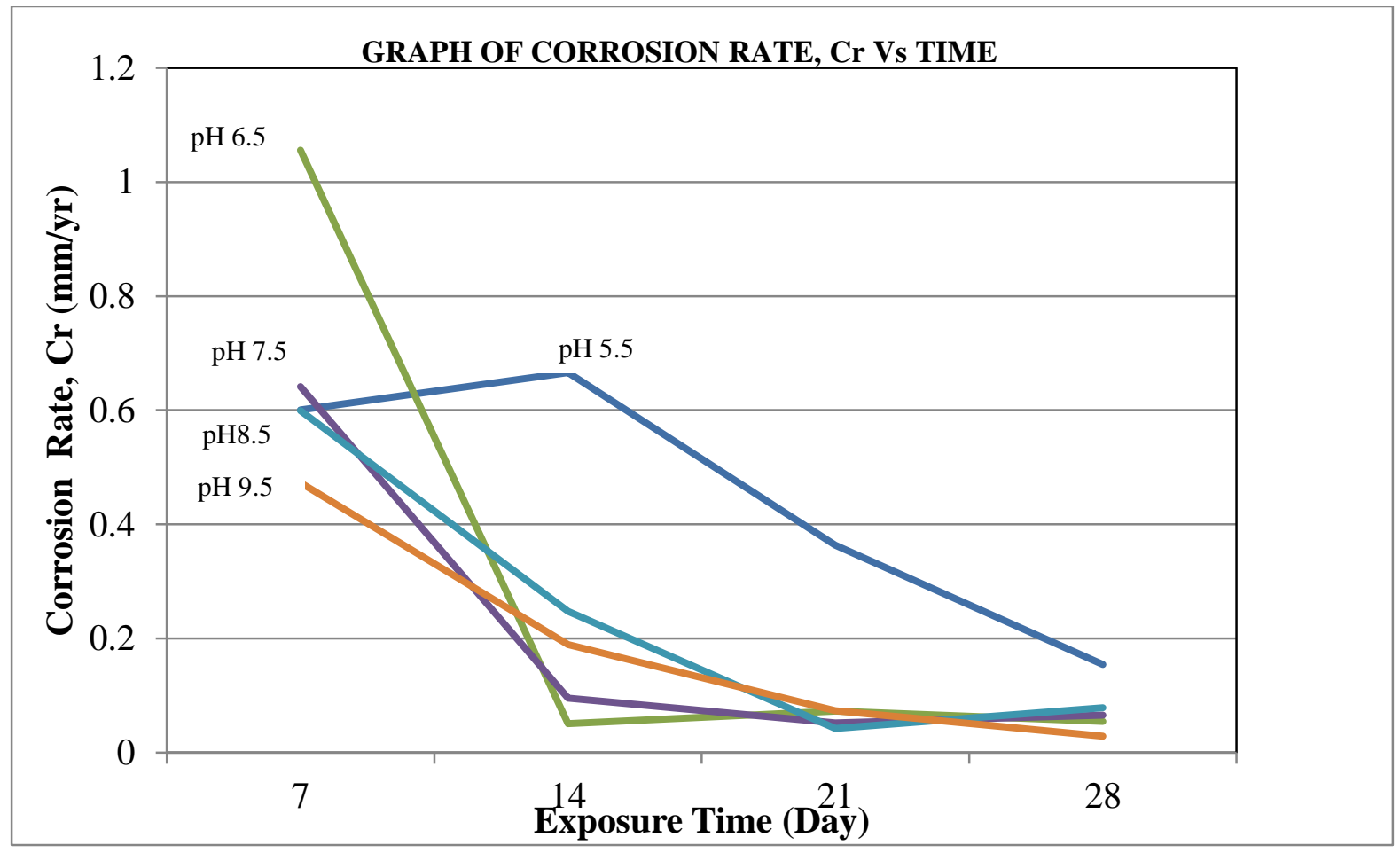

Figure 4.3 : Corrosion rate against exposure time for $\mathrm{pH}$

\section{Conclusion}

From the experiment, the result shows that the $\mathrm{SRB}$ growths are effected by the medium $\mathrm{pH}$. The findings from the study are the optimum SRB growth is at range $\mathrm{pH} 5.5$ to 6.5 and at $\mathrm{pH} 6.5$ with the value of $\mathrm{Cr}$ is $1.056005318 \mathrm{~mm} /$ year $(\approx 1.056 \mathrm{~mm} /$ year $)$. 
From the tested $\mathrm{pH}$, the SRB growths faster from day 1 until day 7 (Refer to Table 4.2) where the Cr value are between 0.4 to $0.65 \mathrm{~mm} /$ year. After day 7 , the bacteria growth is decreasing. Accept for $\mathrm{pH} 5.5$, the optimum bacteria growth at day 14 . Table 5.1 show the optimum parameter for SRB growth.

Table 5.1 : Summary on optimum parameter for SRB growth

\begin{tabular}{cccc}
\hline Parameter & $\begin{array}{c}\text { Exposure Time, } \mathbf{T} \\
(\text { Day })\end{array}$ & $\begin{array}{c}\text { Corrosion Rate, } \mathbf{C r} \\
(\mathbf{m m} / \mathbf{y r})\end{array}$ & $\begin{array}{c}\text { Optimum SRB } \\
\text { Growth }\end{array}$ \\
\hline $\mathrm{pH}$ & $7-14$ & 1.056 & $\mathrm{pH} 5.5-\mathrm{pH} 6.5$ \\
\hline
\end{tabular}

Previous study shows that the $\mathrm{Cr}$ at the beginning of the test is higher than the $\mathrm{Cr}$ value corresponding to 8,16 and 32 days of the exposure time. This behavior should be attributed to the fact that at the beginning of the test, the surface of the steel sample is active; because no corrosion film or biofilm (film produced by metabolism activities of SRB) covered this surface consequently the $\mathrm{Cr}$ value are high. SRB activity influenced the overall corrosion because the biofilm produced by the metabolism of this SRB can passivize the X70 steel [12].

The relationship between $\mathrm{pH}$, corrosion rate and exposure time is that, the $\mathrm{pH}$ decreases as the exposure time increase and the $\mathrm{Cr}$ increase. It is difficult to do the correlation between temperature and $\mathrm{pH}$ from the study because the bacteria growth will change the environment parameter of the medium. Previous study reveals that Hydrogen sulphide generated by the metabolism of SRB during its growing process caused the change of environment parameter. The environment parameter in the study is sulphide concentration and $\mathrm{pH}$ values [13].

\section{REFERENCES}

[1] Yingbo Huo, Deqing Lei, Shujin Li, Wei Yang and ChuQing $\mathrm{Li}$ (2016) Experimental Investigation on Corrosion Effect on Mechanical Properties of Buried

[11] Robert Babolan (2005). Corrosion Tests and Standard: Application and Interpretation, ASTM International Second Edition ISBN 0-8031-2098-2

[12] M. Rodriguez-Hernandez, R. Galvan-Martinez*, R. Orozco-Cruz, E. A. Martinez and R. Torres-Sanchez (2009). Influence of the Sulphate Reducing Bacteria
Metal Pipes International, Journal of Corrosion Volume 2016 (2016), Article ID 5808372, 13 pages

[2] Ir. Razmahwata bin Mohamad Razalli (2005) THE Malaysian Oil And Gas Industry : An Overview, IEM Bulletin Jan2005 (2005), ISSN 0126-9909 Bil.2005 No.01 January 2005, page 8

[3] Nyborg, R. (2007). Corrosion control in oil and gas pipeline. 2nd Ed., Norway, 2007

[4] Gregory, R.R.; and Mohammed, A.A. (2006). Oil and gas exploration and production, CC Technology Laboratories, Inc., Dublin, Ohio.

[5] Akinyemi O. O., Nwaokocha C. N., Adesanya A. O. (2012). Evaluation Of Corrosion Cost Of Crude Oil Processing Industry, Journal of Engineering Science and Technology Vol. 7, No. 4 (2012) 517 - 528

[6] Elaine Bowman (2014). New Global Corrosion Cost Study: Published NACE International News for the East Asia and Pacific Area

[7] Dake Xu1 \& Tingyue Gu (2015). The War against Problematic Biofilms in the Oil and Gas Industry, Microb Biochem Technol 2015, 7:5 http://dx.doi.org/10.4172/1948-5948.1000e124

[8] ASTM G1-03 (2011), "Standard Practice for Preparing, Cleaning, and Evaluating Corrosion Test Specimens," American Society for Testing and Materials, PA, 2011.

[9] Zuraini Din (2014). The Influence of SRB (ATCC 7757) On The Corrosion of Oil And Gas API X70 Steel Pipe. Universiti Tun Hussein Onn Malaysia

[10] ASTM G4/95 (2001) ASTM G4. Standard Guide for Conducting Corrosion Coupon Tests in Field Applications. Annual Book of American Society for Testing and Materials Standards 3.02. 2001. pp. 4957.

on API-X70 Steel Corrosion, Material and Corrosion, 60, No. 12

[13] Fei Kuang, Jia Wang, Li Yan, Dun Zhang (2007). Effect of Sulfate-reducing Bacteria on the Corrosion Behavior of Carbon Steel, ScienceDirect 